Article

\title{
Assessing Groundwater Withdrawal Sustainability in the Mexican Portion of the Transboundary Santa Cruz River Aquifer
}

\author{
Elia M. Tapia-Villaseñor ${ }^{1, *}$, Eylon Shamir ${ }^{2}$, Mary-Belle Cruz-Ayala ${ }^{3}$ and Sharon B. Megdal ${ }^{3}$ \\ 1 Departamento de Geología, Universidad de Sonora, Hermosillo 83000, Mexico \\ 2 Hydrologic Research Center, San Diego, CA 92127, USA; eshamir@hrcwater.org \\ 3 Water Resources Research Center, The University of Arizona, Tucson, AZ 85719, USA; \\ marybelca@email.arizona.edu (M.-B.C.-A.); smegdal@arizona.edu (S.B.M.) \\ * Correspondence: elia.tapia@unison.mx
}

Citation: Tapia-Villaseñor, E.M.; Shamir, E.; Cruz-Ayala, M.-B.; Megdal, S.B. Assessing Groundwater Withdrawal Sustainability in the Mexican Portion of the Transboundary Santa Cruz River Aquifer. Water 2022, 14, 233. https:// doi.org/10.3390/w14020233

Academic Editor: Pankaj Kumar

Received: 30 September 2021

Accepted: 3 January 2022

Published: 13 January 2022

Publisher's Note: MDPI stays neutral with regard to jurisdictional claims in published maps and institutional affiliations.

Copyright: (c) 2022 by the authors. Licensee MDPI, Basel, Switzerland. This article is an open access article distributed under the terms and conditions of the Creative Commons Attribution (CC BY) license (https:// creativecommons.org/licenses/by/ $4.0 /)$.
Abstract: The impact of climate uncertainties is already evident in the border communities of the United States and Mexico. This semi-arid to arid border region has faced increased vulnerability to water scarcity, propelled by droughts, warming atmosphere, population growth, ecosystem sensitivity, and institutional asymmetries between the two countries. In this study, we assessed the annual water withdrawal, which is essential for maintaining long-term sustainable conditions in the Santa Cruz River Aquifer in Mexico, which is part of the U.S.-Mexico Transboundary Santa Cruz Aquifer. For this assessment, we developed a water balance model that accounts for the water fluxes into and out of the aquifer's basin. A central component of this model is a hydrologic model that uses precipitation and evapotranspiration demand as input to simulate the streamflow into and out of the basin, natural recharge, soil moisture, and actual evapotranspiration. Based on the precipitation record for the period 1954-2020, we found that the amount of groundwater withdrawal that maintains sustainable conditions is $23.3 \mathrm{MCM}$ /year. However, the record is clearly divided into two periods: a wet period, 1965-1993, in which the cumulative surplus in the basin reached 380 MCM by 1993, and a dry period, 1994-2020, in which the cumulative surplus had been completely depleted. Looking at a balanced annual groundwater withdrawal for a moving average of 20-year intervals, we found the sustainable groundwater withdrawal to decline from a maximum of $36.4 \mathrm{MCM} / \mathrm{year}$ in 1993 to less than $8 \mathrm{MCM}$ /year in 2020. This study underscores the urgency for adjusted water resources management that considers the large inter-annual climate variability in the region.

Keywords: Santa Cruz River Aquifer; Mexico; water balance model; climate uncertainty; transboundary aquifer; transboundary aquifer assessment; Arizona; Sonora

\section{Introduction}

According to the International Groundwater Resources Assessment Centre (IGRAC), a total of 468 transboundary aquifers have been identified worldwide [1], a figure that has steadily increased over the last decade due to advances in transboundary aquifer assessment. Groundwater from transboundary aquifers constitutes a significant source of fresh water for the environment and numerous communities in almost every nation [2,3], representing a valuable, invisible, and finite resource that needs to be managed sustainably.

Historically, the United States and Mexico have engaged in insightful binational cooperation and dialogue regarding water resources. A vivid example of such cooperation, the 1994 Treaty for the Utilization of Waters of the Colorado and Tijuana Rivers and of the Rio Grande, along with its interpretations (Minutes), addresses specific border, environmental, and water-related issues. Yet, U.S.-Mexico relations surrounding water resources have not been exempted from conflict, such as the diplomatic dispute regarding the United States 
unilateral decision to build the All-American Canal in California that affected groundwater recharge in Mexican territory. In addition, the institutional asymmetries between the two countries, which are detailed in [2,4,5], could also jeopardize possible cooperation on water resources management, as described by [6]. Fortunately, among other outcomes, cooperation between the United States and Mexico has resulted in transboundary-aquifer assessment efforts to improve the understanding of their shared water resources.

A solid scientific foundation on groundwater resources is a needed first step in developing groundwater management strategies in transboundary settings [2]. It is also essential in places that rely on groundwater resources for their basic activities or are currently affected by climate uncertainties, such as the Transboundary Santa Cruz Aquifer (TSCA) shared between the United States and Mexico [3] (Figure 1). Water supply in the TSCA, the binational aquifer recharged by the Santa Cruz River, is highly sensitive to climate variability and largely depends on compliance of local and international water and wastewater transfer agreements (e.g., [3,7-9]). The TSCA recharge results from riverbed infiltration and mountain front recharge in Mexico and the United States. Thus, the TSCA is a binational aquifer in which the water-resources management and natural processes on one side of the border directly impact the neighboring country.

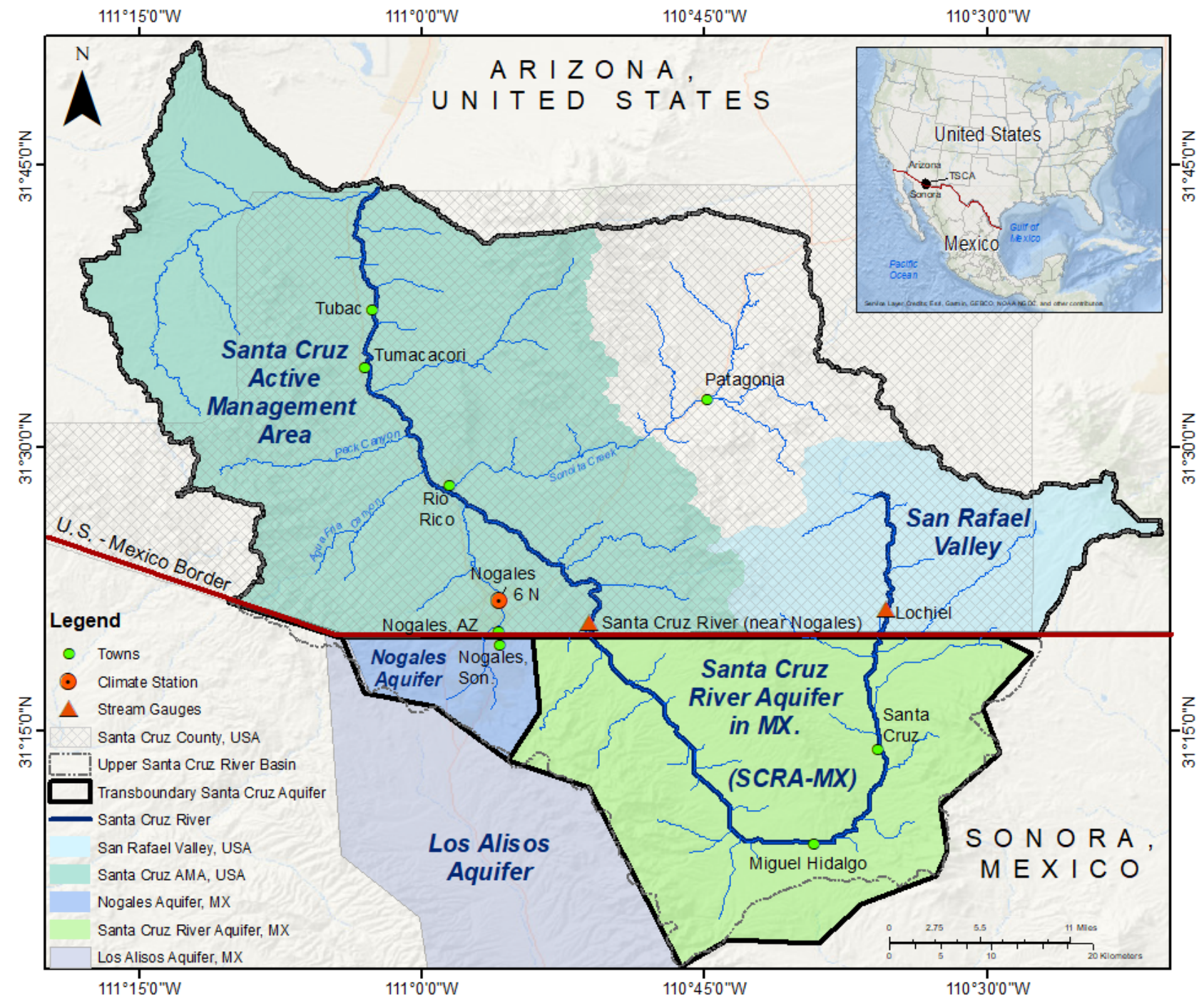

Figure 1. Political-administrative domains in the Transboundary Santa Cruz Aquifer.

Because of the region's scarce water resources, population increase, and growing groundwater demands on both sides of the border, the TSCA was selected for the U.S.- 
Mexico Transboundary Aquifer Assessment Program (TAAP). The TAAP was signed in 2009 by the principal engineers of the International Boundary and Water Commission (IBWC) and aimed to improve the knowledge of U.S.-Mexico transboundary aquifers [10]. The principles of the TAAP Cooperative Framework include elements that promote trust between the United States and Mexico (e.g., data sharing, development of binational aquifer assessment activities, the establishment of technical advisory committees, and the establishment of technical groups). These elements are crucial to maintaining the binational cooperation necessary when researching shared aquifers. Transboundary aquifer assessments worldwide have effectively employed these elements, including the Guarani, Nubian Sandstone, Saharan Aquifer, and Genevese Aquifer [2]. This study is part of the TAAP's effort to better understand the TSCA, particularly in the Mexican portion of the aquifer.

The TSCA comprises four political-administrative domains: the Santa Cruz Active Management Area (SCAMA) in Arizona, with an areal extent of 1,854.43 square kilometers $\left(\mathrm{km}^{2}\right)$; the San Rafael Valley, with an areal extent of approximately $465 \mathrm{~km}^{2}$; the Nogales Aquifer in Mexico, with an areal extent of $120 \mathrm{~km}^{2}$; and the Santa Cruz River Aquifer in Mexico (SCRA-MX), with an areal extent of $952 \mathrm{~km}^{2}$ (Figure 1). The region's water supply relies on a relatively limited-storage, alluvial aquifer system underneath the Santa Cruz River Valley. The dominant source of recharge for the aquifer is the episodic streamflow events in the intermittent Santa Cruz River and its ephemeral desert tributaries. These episodic streamflow events are triggered by highly variable, seasonal (winter and summer) precipitation events (e.g., [7]). Thus, due to this region's limited groundwater storage and its reliance on episodic streamflow events, even small changes in groundwater recharge patterns coupled with increased water demand from border communities can adversely affect the water-supply reliability. Additionally, precipitation projections for the Upper Santa Cruz River Basin point to significant uncertainty and increased interannual variability, which will likely challenge water providers in meeting the water demands of the border communities $[3,7,9,11]$.

Though previous studies have analyzed water resources in different portions of the TSCA, only a few have addressed the Santa Cruz River Aquifer in Mexico (SCRA-MX). For instance, studies have assessed the impact of urban growth on water resources, focusing on the "Ambos Nogales" region, which is located within the Nogales Aquifer and the SCAMA regions in Mexico and the United States [12,13]. Other studies developed ecosystem-services tools to assess the impacts of climate change and urban growth in the U.S. portion of the Santa Cruz Watershed [14] and to evaluate flood risk in the Ambos Nogales region, considering various scenarios of land-use changes [15]. In addition, climate change and water-resources assessments through hydrologic frameworks have also been developed for the SCAMA, attempting to bridge the gap between scientific findings and stakeholders $[3,7,8,16,17]$.

Studies focusing on the SCRA-MX include hydrogeological characterizations of the aquifer [18], regional studies that assessed the impacts of climate change on local water resources [11,19], and the water availability reports published by the National Water Commission in Mexico (CONAGUA) [20-23]. These studies have improved the knowledge of the TSCA and have helped to develop tools that assist with water-resources-management decisions. However, a deeper understanding of the TSCA system, particularly the SCRAMX, is needed to develop management strategies focused on groundwater sustainability.

Sustainable groundwater withdrawal can be generally defined as the amount of water that can be withdrawn from an aquifer without causing undesirable environmental, economic, or social consequences $[24,25]$. Undesirable outcomes of unsustainable groundwater withdrawal may include a decrease in water availability for populations and the environment, a deterioration of the groundwater quality, riparian vegetation die-off, an intrusion of contaminated water or seawater, and land subsidence. This study aims to identify, through a water-balance model, the annual groundwater-withdrawal rate from the SCRA-MX that maintains sustainable conditions. Although sustainable groundwater withdrawal can have 
various definitions and nuances, we define groundwater-withdrawal sustainability as the withdrawal rate that maintains a multi-year balance between the water fluxes into and out of the basin.

\section{Study Area}

From its headwaters in the San Rafael Valley in Arizona, the Santa Cruz River flows southward to cross the U.S.-Mexico border into Sonora, Mexico. The river then curves northward and returns to the United States, just east of Nogales, Arizona; from there, it flows north to merge with the Gila River, a tributary of the Colorado River (Figure 1).

In the Mexican territory, water from the TSCA is primarily used by the city of Nogales and the town of Santa Cruz. According to Mexico's 2020 census, the number of registered residents was 264,782 and 1,835 in Nogales and the town of Santa Cruz, respectively. These numbers mark a $20.2 \%$ population increase for Nogales and an $8.16 \%$ decrease for the town of Santa Cruz compared with the 2010 census. On the other side of the border, in the 2020 census for Nogales, Arizona, the population declined from 20,837 (2010) to 19,770 (2020). During the same period, the total population in Santa Cruz County, Arizona, was almost unchanged (47,420 in 2010 and 47,669 in 2020).

In Mexico, the national Law of the Nation's Waters (in Spanish, Ley de Aguas Nacionales, or LAN), signed in 1992, defines the role of the National Water Commission (CONAGUA) as the federal agency responsible for water management. Grounded in the Constitution, the LAN ordains in Article 20 that "the exploitation, use, or non-consumptive use [e.g., energy production] of the nation's water resources should be carried out through a concession or asignación (in Spanish) granted by the Federal Executive Branch or Basin Councils" [26,27]. Asignación is the legal term that the legislation utilizes to describe water appropriation for urban or domestic purposes. This appropriation cannot be transferred to other users. A concession defines the amount of water that can be extracted from a specific well/aquifer. The duration of concessions ranges from five to thirty years, and users can apply for an extension [28]. The concessions and asignaciones are registered in the Public Registry of Water Rights (in Spanish, Registro Público de Derechos de Agua, or REPDA).

CONAGUA is also responsible for publishing groundwater availability reports for each aquifer in the Official Federal Gazette (in Spanish, Diario Oficial de la Federación, or DOF). These reports, which are published every three years, guide the appropriations of water concession and allocation volumes. In CONAGUA reports, water balance models are used to assess groundwater availability. The premise of these water balance models is that the Mean Annual Groundwater Availability for a given aquifer is equal to the difference between Mean Annual Recharge and the Mean Annual Groundwater Extractions and the Natural Discharge for environmental needs. For example, in 2020, CONAGUA published groundwater availability reports for 653 aquifers and reported the available volume for appropriation in the SCRA-MX to be $33.85 \mathrm{MCM} /$ year [29]. It should be noted that the actual volume of groundwater withdrawal is often not monitored by CONAGUA and may therefore deviate from REPDA's authorized volumes.

In the SCRA-MX groundwater concessions and asignaciones have increased from 19.2 MCM/year in 1995 to 33.85 MCM in 2020 (Figure 2) [30]. This increase is primarily attributed to a gradual increase in appropriated concessions for agriculture, from 0 in 1995 to approximately $9 \mathrm{MCM}$ /year in 2020. Additional appropriation of approximately $2 \mathrm{MCM} /$ year was allocated since 2011 to the industrial sector for supporting copper mining operations.

In the Nogales Aquifer in Mexico (Figure 1), groundwater allocations (concessions and asignaciones) have ranged from $0.003 \mathrm{MCM} /$ year to $1.37 \mathrm{MCM}$, since 1997. It is important to note that additional water has been transferred for decades from both the SCRA-MX and Los Alisos aquifers to supply the water needs of the city of Nogales [3,23,31]. According to CONAGUA, since 1997, most concessions authorized in the Nogales Aquifer have been industrial, consistent with the main economic activity reported by the Ministry of Economy (Figure 2). In comparison, most of the groundwater volume allocated for the SCRA-MX 
is dedicated to urban-public services. Concessions in the SCRA-MX for livestock and industrial activities have increased since 2011 (Figure 2). Data published by the Ministry of Economy in 2019 show that the agricultural and mining sectors of the Nogales and Santa Cruz municipalities have registered minimal increases in their economic activity during this period [32].

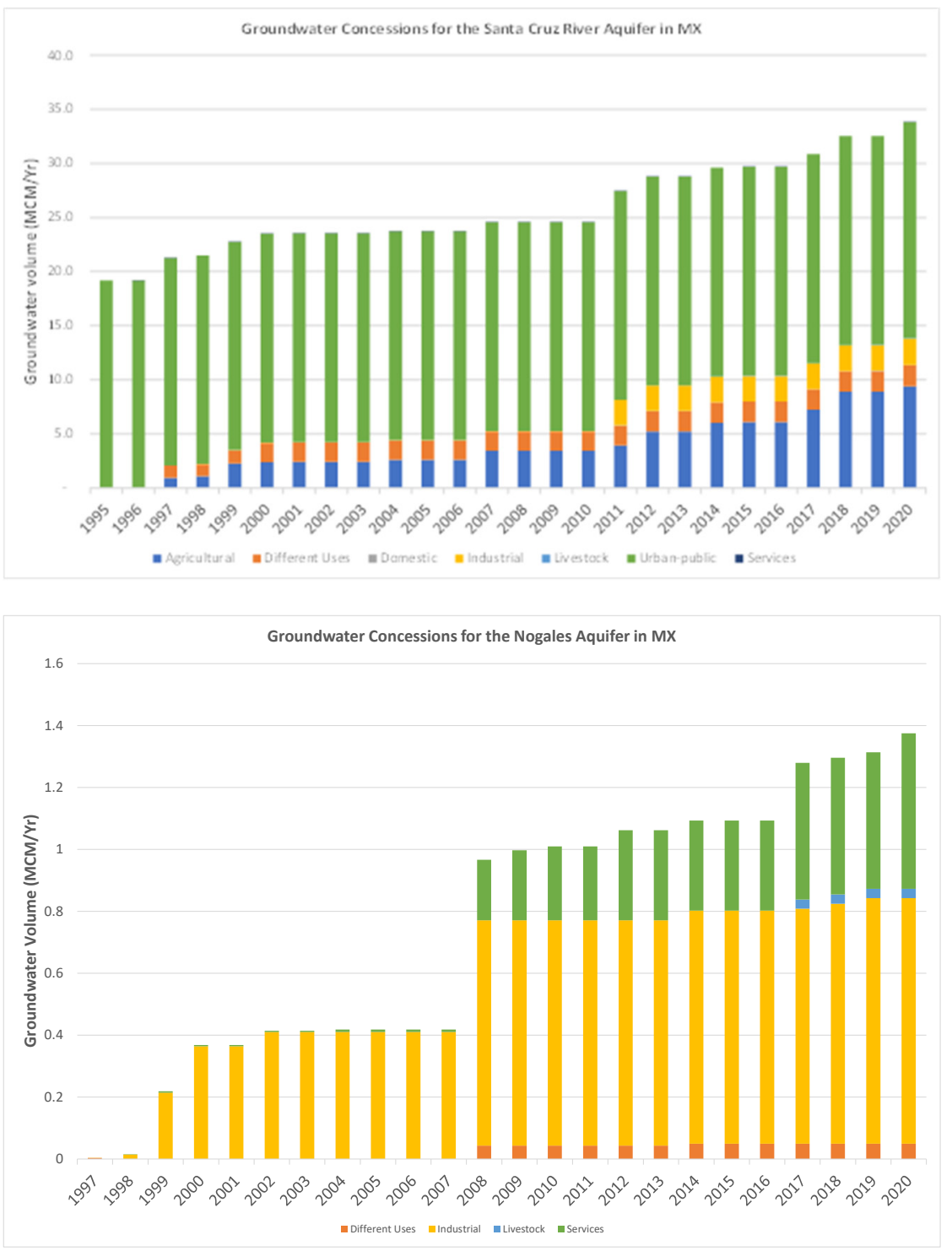

Figure 2. Groundwater Concessions (Asignaciones) in the Santa Cruz River Aquifer in Mexico and the Nogales Aquifer. Source: REPDA (2020) [30].

\section{Materials and Methods}

Our study assessed the amount of annual groundwater withdrawal that maintains long-term sustainable conditions in the SCRA-MX. Sustainable groundwater withdrawal can be generally defined as the amount of water that can be withdrawn from the aquifer without causing undesirable environmental, economic, or social consequences [24,25]. Undesirable implications due to unsustainable groundwater withdrawal may include the decrease in water availability for populations and the environment, deterioration of the groundwater quality, riparian vegetation die-off, intrusion of contaminated water, intrusion of seawater, and land subsidence.

Within the U.S. side of the border, the term safe yield is often used to describe a management goal that maintains sustainable conditions. Safe yield is defined by ADWR as a 
groundwater management goal that attempts to achieve and maintain a long-term balance between the annual amount of groundwater withdrawn and the annual amount of natural and artificial recharge (A.R.S. § 45-561(12)). The terms "safe yield" and "sustainability", with respect to groundwater management, are often interchangeably used. Safe yield was historically defined as the attainment and maintenance of a long-term balance between the amount of groundwater withdrawn and the amount of recharge (e.g., [33]). Adhering to this definition, in order to reach safe yield conditions, groundwater withdrawal should not exceed natural recharge. This practice, however, ignores other long-term water fluxes out of the basin such as discharge, evapotranspiration, or springs that extract unaccounted for groundwater, which eventually may deplete the aquifer. Regardless of the term selection, the selected term should be clearly defined for each specific aquifer considering its management goals and the potential hydrologic, economic, or ecologic harms inflicted by unsustainable management [34].

To estimate the amount of annual withdrawal that maintains sustainable conditions, we used a modeling framework that consisted of a water balance model (WBM) and a hydrologic model. The WBM was developed to account for all annual water fluxes into and out of the basin of the SCRA-MX and to calculate the long-term cumulative water deficits or surpluses. In an arid environment that relies on highly inter-annual climatic variability and therefore highly variable year-to-year natural recharge, the deficits and surpluses should be assessed over multiple years. For instance, the current ADWR recommendation for a quantitative assessment of safe yield is to consider a 20-year moving average interval for the natural components of the water budget (e.g., natural recharge) and a three-year running average for the artificial components (e.g., groundwater withdrawals and incidental recharge). In our study, we assessed the sustainable withdrawal by first considering the entire period of the historical record (1954-2020) and second, by considering 20 year moving averages, as recommended by ADWR.

\subsection{Water Balance Model}

Adapted from CONAGUA (2020) [23], the annual mass balance in the SCRA-MX basin is calculated using the following equation:

$$
\Delta S=Q_{\text {in }}+\mathrm{GW}_{\text {in }}+\mathrm{Re}+\mathrm{Ag}-\mathrm{Q}_{\text {out }}-\mathrm{GW}_{\text {out }}-\mathrm{ET}-\mathrm{Pu}
$$

where $\Delta S$ represents the annual positive or negative water storage changes in the aquifer and vadose zone, $Q_{\text {in }}$ and $Q_{\text {out }}$ are the Santa Cruz River streamflow in and out of the basin. $\mathrm{GW}_{\text {in }}$ and $\mathrm{GW}_{\text {out }}$ are the groundwater fluxes into and out of the basin; Re is the natural groundwater recharge component; Ag is the return flow from irrigated agriculture; ET is the actual evapotranspiration losses; and $\mathrm{Pu}$ is the groundwater withdrawal. The units for all the terms in Equation (1) are million cubic meters per year (MCM/year). CONAGUA's water balance model results for the SCRA-MX basin are in Table 1.

Table 1. CONAGUA's WBM components for 2020 (MCM/year). Source: CONAGUA (2020) [23].

\begin{tabular}{|c|c|c|c|c|c|c|}
\hline \multicolumn{3}{|c|}{ Inflows } & \multicolumn{3}{|c|}{ Outflows } & \multirow{2}{*}{$\Delta S$} \\
\hline $\mathrm{GW}_{\text {in }}$ & Ag & $\operatorname{Re}$ & $\mathbf{P u}$ & $\mathrm{GW}_{\text {out }}$ & ET & \\
\hline 10.2 & 4.1 & 23.8 & 26.4 & 2.0 & 8.8 & 0.9 \\
\hline
\end{tabular}

In this study, we solved the WBM equation to determine the groundwater withdrawal $\mathrm{Pu}$ ) that maintains the long-term changes of $\Delta S$ in sustainable conditions. This simulation was implemented at an annual time step to assess the overall long-term balance. In the following section, we describe the WBM components considered in this study.

\subsection{Precipitation}

Hourly precipitation time series are needed as input to the hydrologic model. Hourly precipitation records since 1949 are available from the Nogales 6N station (USC00025924; 
W110.968, N31.4554, $1055 \mathrm{~m}$ ) from the US National Weather Service (Figure 1). However, we found many disagreements when this record was compared to the 1954-2020 daily quality-controlled dataset from the same station. We decided, therefore, to use the daily time series and disaggregate it to hourly (see Figures S1-S6). The disaggregation was carried out by using the hourly time series to identify the hourly diurnal distribution with reported daily precipitation days. If hourly events were unavailable for the target date, we selected from the hourly time series a rainy day within a short duration from the target date.

The hourly precipitation was then spatially interpolated over the study area using the 1958-2020, $\sim 4 \mathrm{~km}^{2}$ gridded monthly rainfall, available from the TerraClimate dataset [35]. The interpolation was carried out by using the ratios of the station's grid cell with the other TerraClimate grid cells for the matching months. These ratios were used as multipliers for the interpolation to derive $4 \mathrm{~km}^{2}$ hourly time series. Prior to 1958 , a randomly selected month from the same wetness tercile as the station's record was used for the interpolation. The interpolated $4 \mathrm{~km}^{2}$ grid was then averaged over the area of the modeling units to derive the hourly Mean Areal Precipitation (MAP) time series, which were used as input to the hydrologic model. This spatial interpolation method assumes that the Nogales gauge well represents the occurrence of hourly events over the study area, and that the hourly rainfall distribution throughout the month is uniformly distributed in space. These assumptions are particularly challenged during the North American Monsoon summer rainfall characterized by small-scale local convective thunderstorms.

\subsection{Streamflow $\left(Q_{\text {in }}\right.$ and $\left.Q_{\text {out }}\right)$}

Observations of surface inflow and outflow to and from the Mexican portion of the Santa Cruz River are available from the USGS hydrometric stations at Lochiel (USGS 09480000) and near Nogales (USGS 09480500). The Lochiel hydrometric station, approximately $2.5 \mathrm{~km}$ north of the international border (Latitude $31^{\circ} 21^{\prime} 19^{\prime \prime}$, Longitude $110^{\circ} 35^{\prime} 20^{\prime \prime}$, $1400 \mathrm{~m}$ above sea level), drains $209 \mathrm{~km}^{2}$ of the Santa Cruz River headwater at the San Rafael Valley and parts of the Patagonia and Huachuca Mountains. It has a daily streamflow record for the period January 1949-August 2014 and from May 2019 to present. Approximately one kilometer north of the international border, the Nogales hydrometric station (Latitude $31^{\circ} 20^{\prime} 40^{\prime \prime} \mathrm{N} 110^{\circ} 51^{\prime} 03^{\prime \prime} \mathrm{W}, 1120 \mathrm{~m}$ above sea level) drains an area of $1364 \mathrm{~km}^{2}$. It has a daily streamflow record from 1913 to the present, with some missing years during the 1920s. We note that although the 1954-2020 observed average streamflow out of the basin was $22.1 \mathrm{MCM}$ /year (range 0-181 MCM/year), the streamflow out of the basin was likely generated from rainfall over the basin and therefore was not considered as a negative flux in Equation (1).

For this study, a hydrologic model was used to simulate the inflow and outflow (i.e., $Q_{\text {in }}$ and $Q_{\text {out }}$ ) as a function of precipitation. The hydrologic model we used is the Sacramento Soil Moisture Accounting (SAC-SMA) model [36], as it was configured for this basin by the Colorado Basin River Forecast Center (CBRFC), U.S. National Weather Service (see Figures S7 and S8).

The SAC-SMA model is a continuous hydrologic model that keeps track of the water content at the basin's top and subsoil layers. It uses precipitation and evapotranspiration (ET) demand as input to simulate runoff, recharge, actual evapotranspiration, and soil moisture. The CBRFC's primary purpose is to warn for high-flow events. Therefore, they focused their SAC-SMA model calibration on capturing episodic flow events. In our study, the model was used to account for the overall streamflow influx into the area of interest. Therefore, the model required additional calibration to capture the range of flow regimes. The calibration was carried out by comparing the simulated streamflow on the Santa Cruz River in Lochiel and near Nogales to observed flow from the USGS gauges. The assessment was carried out for ranging time scales of daily, seasonal, and annual flows. The CBRFC SAC-SMA model configuration for the SCRA-MX basin is based on three hydrologic units. The first hydrologic unit $\left(210 \mathrm{~km}^{2}\right)$ drains the headwater of the Santa Cruz River to the US-Mexico border crossing. The second and third hydrologic units are the upper and lower 
parts of the SCRA-MX basin, respectively. The upper part of the basin $\left(617 \mathrm{~km}^{2}\right)$ drains areas higher than 1515 meters, while the lower part of the basin $\left(537 \mathrm{~km}^{2}\right)$ drains areas lower than 1515 meters. In our implementation, the surface runoff generated by the lower part of the basin was considered for the flow simulation at the outlet.

The runoff from the upper part, below $50 \mathrm{~m}^{3} / \mathrm{sec}$ was considered as the groundwater recharge component. This assumption is warranted, as it is seen that most of the flow at the Nogales gauge is attributed to local rainfall events. During large storms in the upper basin, the flow contribution to the basin's outlet is delayed and later appears as baseflow $[7,16]$.

In Table 2, summary statistics for the 1954-2020 estimated annual recharge are provided. Notice that CONAGUA (2020) [23] estimated the vertical recharge at 23.8 MCM/year, comparable to our estimated annual average. However, as it is apparent from the values presented in Table 2, the large inter-annual variability of the groundwater recharge may not be well represented by the sample's first-moment indicator.

Table 2. The 1954-2020 estimated recharge in the SCRA-MX.

\begin{tabular}{ll}
\hline Estimated Recharge (MCM/Year) & \\
\hline Average & 25.8 \\
Median & 20.1 \\
Standard Deviation & 22.8 \\
Minimum & 0.7 \\
Maximum & 104.5 \\
\hline
\end{tabular}

\subsection{Groundwater ( $G W_{\text {in }}$ and $\left.G W_{\text {out }}\right)$}

The border crossing groundwater inflow and outflow mainly occur at the alluvial aquifer underneath the river's channel bed. These fluxes are not measured and are estimated from previous studies. Although these fluxes are likely dependent on the aquifer pressure gradients near the international border, we assume constant groundwater fluxes. In our analysis, we adopted CONAGUA (2020) [23] estimate of +10.2 and $-2.0 \mathrm{MCM} /$ year for the $\mathrm{GW}_{\text {in }}$ and $\mathrm{GW}_{\text {out }}$, respectively ('+' indicates a flow from the United States to Mexico and ' - ' indicates a flow from Mexico to the United States). Other studies estimated $\mathrm{GW}_{\text {out }}$ to be 3.5 MCM/year [37], 1.54 MCM/year [38], and 1.66 MCM/year [39].

\subsection{Evapotranspiration (ET)}

Evapotranspiration (ET) from the basin can be divided into ET from the soil, ET from irrigated agriculture fields, and ET from the shallow groundwater aquifer through riparian vegetation and exposed surface water sections of the stream. In Equation (1), the ET variable refers to the latter component. The hydrologic model calculates the ET from the soil, and it is implicitly accounted for in the recharge and streamflow terms. The ET from the agricultural field is considered in the calculation of the agricultural return term. In CONAGUA (2020) [23], the total ET losses from the aquifer were estimated as 8.8 $\mathrm{MCM} /$ year. This estimate assumes that ET from the groundwater is linearly reduced with depth-to-water up to an extinction depth of $10 \mathrm{~m}$. In CONAGUA (2020) [23], the surface area estimate of the aquifer's water levels was provided as a base for the ET estimate. This procedure assumes that the aquifer's water level and the potential evapotranspiration are not changing from year to year.

Using the hydrologic model simulations, we found that the average actual ET from the soil is $314 \mathrm{MCM} /$ year, and the average actual ET is $88 \%$ of the annual precipitation. The actual ET is highly correlated with precipitation and ranges from 130 to $530 \mathrm{MCM}$ /year, 62 to 103 percent of the annual precipitation, respectively. These actual ET estimates are comparable to findings by Minjarez et al. (2011) [19].

\subsection{Agricultural Return Flow ( $A g)$}

To estimate the agricultural return flow, we used the CONAGUA (2020) [23] procedure. It was based on calculations of crop consumptive use, which is the amount of transpired 
water during the growth period of the crop. The agricultural return is then calculated as the irrigated water and precipitation that is in excess of the estimated consumptive use. In CONAGUA (2009 to 2020) [20-23], the irrigated agriculture area was estimated as $8.3 \mathrm{~km}^{2}$ of alfalfa $(60 \%)$, oat $(30 \%)$, and sorghum $(10 \%)$. Using the modified Blaney-Criddle equation [40], the integrated consumptive use of these crops was estimated as $901 \mathrm{~mm} /$ year (7.5 MCM/year), and the agricultural return was estimated as 4.1 MCM/year. In our implementation of the WBM, we used CONAGUA's estimate of consumptive use and the dynamic year-to-year change in precipitation to estimate the groundwater withdrawal that was needed for irrigation. The 1954-2020 average annual precipitation over the agricultural fields was 2.6 MCM/year (range 0.9-5.5 MCM/year), and the average groundwater withdrawal that satisfied the irrigation demand was $4.9 \mathrm{MCM} /$ year, ranging from 1.9 to 6.6 MCM/year. This demand calculation assumes that precipitation occurred during the growing season, and the irrigation was optimized to satisfy the crops' consumptive use. It is important to note that the National Institute of Statistics and Geography (Instituto Nacional de Estadística y Geografía) estimated the irrigated agriculture area in the basin to be $15.7 \mathrm{~km}^{2}$ [41]. Using a $30 \mathrm{~m}$ near-infra-red band of Landsat-8 images from May 2018 and May 2019, our team estimated an area of approximately $17 \mathrm{~km}^{2}$ of agricultural fields. Thus, the water consumption, as well as the areal extent of irrigated agriculture in the basin, is uncertain and requires a comprehensive survey.

\section{Results}

Using 1954-2020 climate dependent recharge, Qin and Ag (as explained above), we solved Equation (1) for the amount of groundwater withdrawal $(\mathrm{Pu})$ yielding a $\Delta \mathrm{S}$ annual average of zero. The Pu that maintains a $1954-2020$ average $\Delta S$ of zero is $23.3 \mathrm{MCM} /$ year. This $\mathrm{Pu}$ is in addition to the $\mathrm{Pu}$ used for irrigation that satisfies the estimated consumptive use of the cultivated fields, as described in CONAGUA (2020) [23]. Using this estimated $\mathrm{Pu}$, the average fraction of the inflow and outflow fluxes from the basin are presented in Figure 3, and the average quantities of these various fluxes are presented in Figure 4 . The largest influx to the basin is the natural recharge, a highly variable flux (see Table 2) that is mainly controlled by the inter-annual variability of precipitation over the SCRA-MX basin.

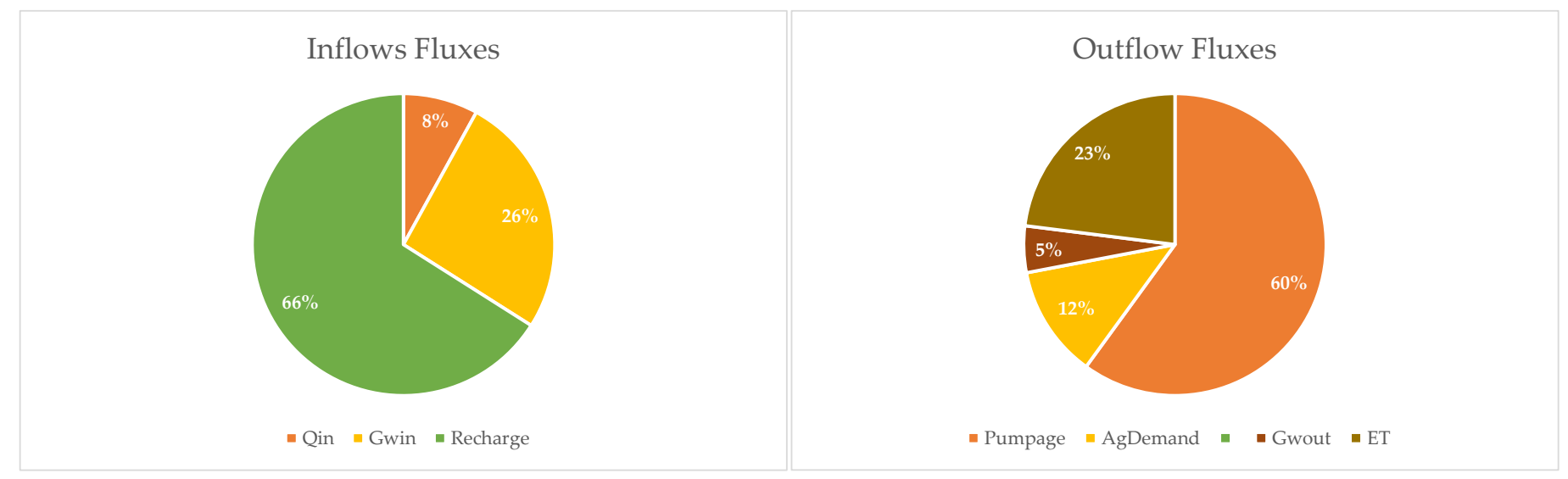

Figure 3. The 1954-2020 average annual percentages of inflow and outflow fluxes to the SCRAMX basin.

The cumulative changes of the $\Delta \mathrm{S}$ using the estimated $\mathrm{Pu}$ of $23.33 \mathrm{MCM}$ are shown in Figure $5 \mathrm{a}$. It is seen that out of the 67 water years, approximately $33 \%$ have shown a surplus while most years ended with a deficit. The cumulative surplus consistently increased from 1965 to reach a surplus of approximately 385 MCM in 1992. These surplus years can be related to frequent El Niño-Southern Oscillation conditions and positive Pacific Decadal Oscillation [8]. However, since 1992, only two years showed an annual surplus (positive $\Delta$ S) and in 2020, the entire surplus that had been gained until 1992 was depleted. These long periods of accrued surplus (1965-1992) and deficit (1995-2020) exemplify the dependence 
of the sustainable $\mathrm{Pu}$ on the period of analysis. The increasing and decreasing trends shown in Figure 5 seem to support ADWR recommendations for examining 20-year intervals, a duration sufficiently long to capture the observed multi decadal trends.

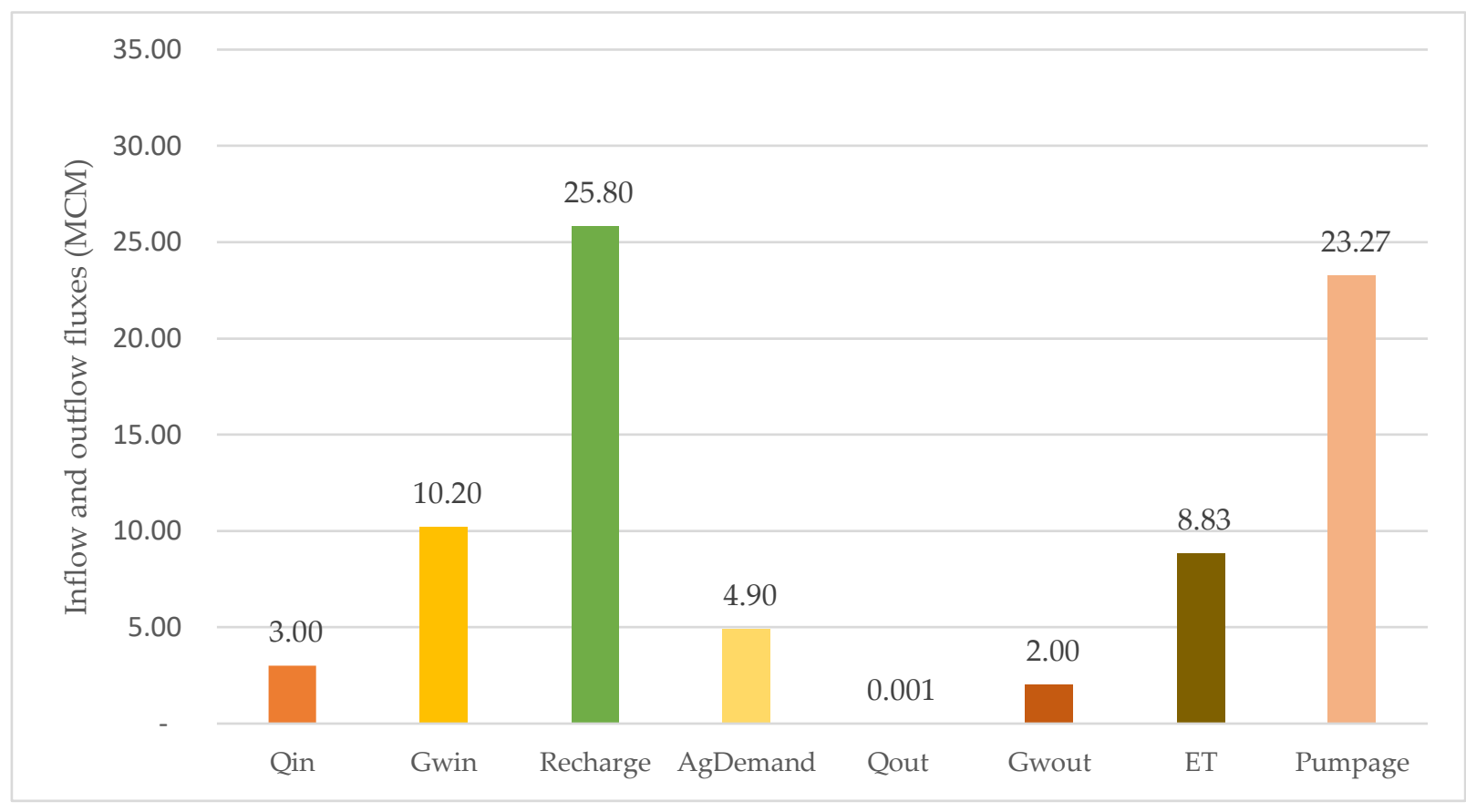

Figure 4. The 1954-2020 average inflow and outflow fluxes for maintaining sustainable conditions.

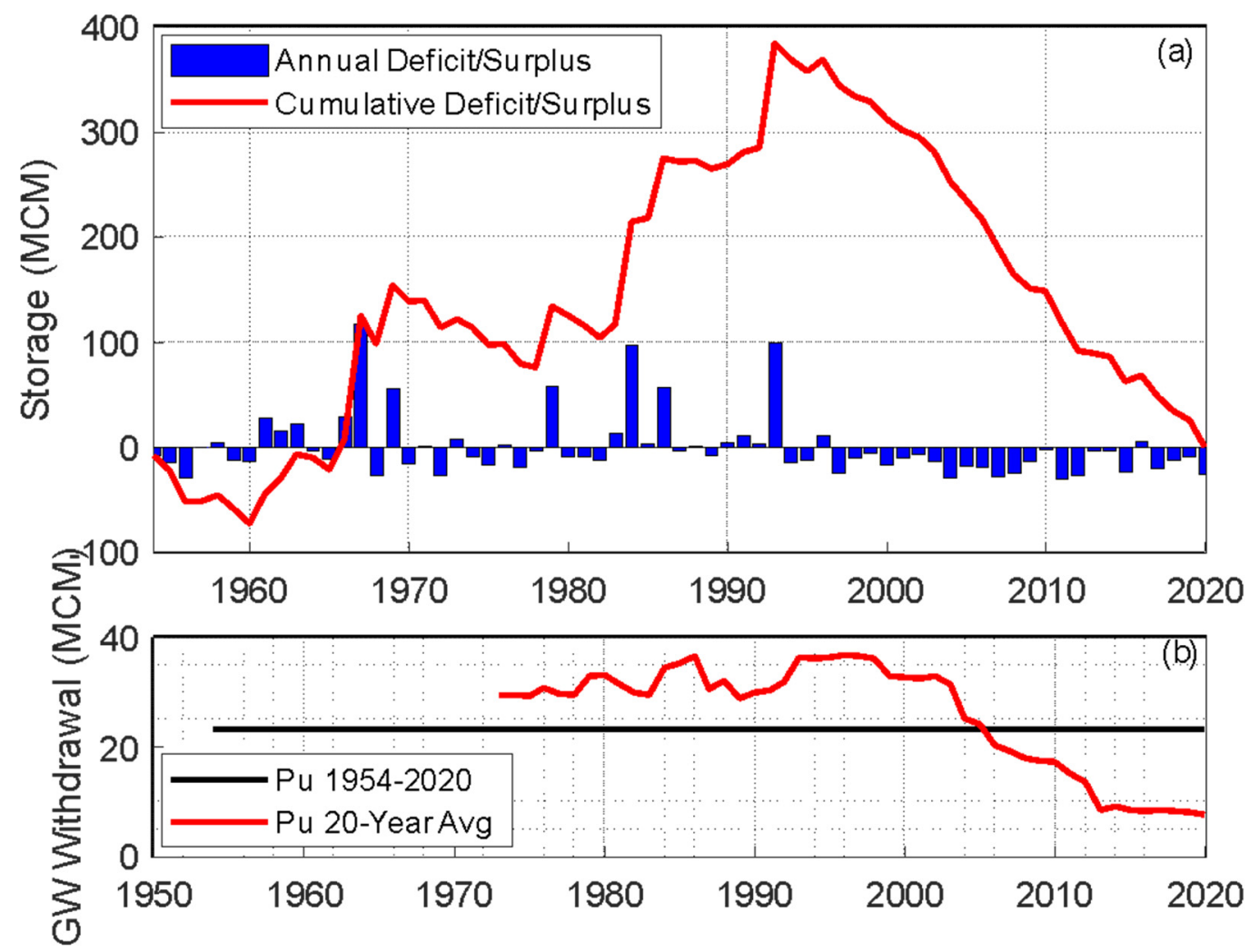

Figure 5. (a) Estimated annual and cumulative storage with annual groundwater withdrawal rate that yields an average of zero storage during the period 1954-2020. (b) Estimated sustainable groundwater withdrawal $(\mathrm{Pu})$ using a 20-year moving average interval (red) and the 1954-2020 duration. 
The fluxes estimated for the WBM can be grouped to three general categories: climate driven annually variable fluxes $\left(\mathrm{Q}_{\mathrm{in}}, \mathrm{Q}_{\text {out }}, \mathrm{Re}\right)$, satisfying water demand fluxes $(\mathrm{Ag}, \mathrm{Pu})$, and constant annual fluxes (GWin, GWout, ET). The first category is based on a hydrologic model that uses sub-daily precipitation and evapotranspiration demand time series as input to simulate the fluxes needed for the WBM. While the simulated $Q_{\text {in }}$ and $Q_{\text {out }}$ were compared to observed streamflow records, the Re estimate cannot be compared to observations. As discussed in the results section, the Re is the largest flux into the basin (Figures 3 and 4) and has large inter-annual variability (Table 2).

Considering moving averages of 20-year intervals, the estimated $\mathrm{Pu}$ is shown in Figure 5b (average Pu of 26.3 MCM/year (ranging from 8.1 to 36.8 and an S.D of 9.6 MCM/year). As expected, the estimated 20-year annual $\mathrm{Pu}$ has continuously declined since the mid-1990s to approximately 9 MCM/year since 2012.

\section{Discussion}

Overall, there has been constant cooperation and dialogue over water resources shared between the United States and Mexico. A remarkable example is the 1944 Water Treaty that has allowed sharing surface water among both countries. However, this agreement does not include groundwater management. This absence has not been addressed, although some steps have been taken-for instance, creating the TAAP that allows technical cooperation between both countries and sharing information on groundwater resources.

The Santa Cruz River Aquifer in Mexico (SCRA-MX) is part of the Transboundary Santa Cruz Aquifer (TSCA), an aquifer shared by the United States and Mexico. The TSCA is located in a semi-arid region characterized by limited groundwater storage, dependency on climate variability, and physical water and wastewater transfers within Mexican territory and between the two countries [3,11,19]. Because of this region's limited groundwater storage and the border communities' reliance on groundwater as their sole resource, even small changes in groundwater recharge patterns coupled with increased water demands can detrimentally impact the water-supply reliability.

Previous efforts on the TAAP have focused on understanding the aquifer characteristics of the TSCA, particularly the U.S. portion of the aquifer e.g., [3,12]. Our study improves the understanding of the SCRA-MX, contributes to the overall knowledge of the binational TSCA, and provides information that could serve as a reference for developing a fully binational water budget model.

This analysis, along with previous studies for the TSCA (e.g., [3,11]), reported a substantial decline in regional precipitation since the early 21 st century. For example, summer and winter precipitation has declined by $10 \%$ and $33 \%$, respectively, according to comparisons of precipitation records from 1955-2000 to 2001-2020. These declines are substantially larger when comparing the same periods of the observed streamflow records out of the SCRA-MX basin (65\% and 78\% for summer and winter flow, respectively) [8].

Moreover, climate model projections for the mid-21st century for the SCRA-MX basin point to changes in precipitation regime, although these changes are highly uncertain e.g., [8]. These projections will pose additional challenges for water providers in meeting the demands for border communities $[3,7,9,11]$. To date, most water resources studies in the TSCA have focused on the Ambos Nogales region or the SCAMA (e.g., [3,7-9]). Excluding the CONAGUA water availability reports, only a few studies have examined the impact of groundwater extractions in the SCRA-MX (i.e., [18,19,38]). In our study, we used a water balance model approach to estimate the amount of groundwater that could be withdrawn from SCRA-MX, while maintaining a long-term balance between water flowing into and out of the basin. Our study only assessed long-term water resources availability while not examining other potential ecological, economic, water quality degradation, or other harms that water resources management practices may cause. Although our analysis yields deterministic estimates for sustainable annual groundwater withdrawal, based on the best available data and information to derive the input for the WBM equation, it is important to note the analysis' main assumptions and the known sources of uncertainties that may have 
influenced the results. The main assumption that may require additional examination is that multi-year cumulative surpluses can be indefinitely stored in the basin and used to compensate for shortages in deficit years. It is likely that the aquifer's storage of surpluses is limited by the size of the aquifer and the dynamic of the groundwater interaction with the stream and atmosphere.

Since natural groundwater recharge is highly variable in space and time, an accurate measure of this dominant flux is impractical. However, additional hydrological and hydrogeological measurements could advance understanding of the basin's hydrological process to potentially reduce the uncertainty in the natural recharge estimate. The uncertainty source in the second category stems from a lack of groundwater withdrawal monitoring. Following CONAGUA's procedure we assumed that the groundwater withdrawal was equal to the appropriated concessions and asignaciones, as reported by REPDA. Additional information is needed to understand how well the appropriated concessions represent the actual groundwater withdrawal in the basin.

An additional source of uncertainty, as discussed before, is the areal appraisal of the cultivated and irrigated fields. The third category of fluxes, which were assigned as constants following CONAGUA's estimates, is also likely to vary in time. The main reason for assigning them as constants is the lack of information and data to understand their temporal variability. With the available information on the economic activities in the Nogales and Santa Cruz municipalities, it is possible to identify a positive relationship between increased industrial activities and water allocations from 2009 to 2020. While the groundwater surplus has reduced since 1995, allocations for agricultural and industrial activities have increased. Considering this trend, it would be desirable that the national authority assess the potential negative impacts of groundwater over-allocation and its availability to maintain a long-term balance between water flowing into and out of the basin.

It is generally possible to monitor groundwater extraction for asignaciones because they are dedicated to public services, for which municipal and state government agencies are responsible for reporting to CONAGUA. However, for groundwater concessions, the monitoring is limited. Additionally, as mentioned above, concessions can be transferred to other users, and although these changes must be reported to CONAGUA, they are often not being promptly reported. Future TAAP efforts on transboundary aquifer assessment include the evaluation of the uncertainty associated with the water balance model that was developed for the TSCA and the identification of specific actions that can substantially reduce uncertainty in WBM simulations. In addition, development of recommendations for a model and data management framework for binational watersheds with similar setting to the TSCA.

\section{Conclusions}

In this study, we assessed the amount of groundwater withdrawal that maintains sustainable conditions in the SCRA-MX, which is part of the TSCA. In this part of the aquifer, the regulatory allocated groundwater concessions had steadily increased from approximately $18 \mathrm{MCM}$ /year in 1995 to approximately $34 \mathrm{MCM} /$ year in 2020. The increase in groundwater withdrawal concessions was primarily attributed to new allocations for agricultural and industrial usage. In this study, we used a water balance model (WBM) that accounts for all the annual water fluxes into and out of the basin to determine the amount of multi-year groundwater withdrawal that maintains sustainable conditions. In our study, "sustainable conditions" is defined as the amount of annual groundwater withdrawal that maintains a long-term difference of zero between the water fluxes into and out of the basin. We developed a hydrologic model to estimate the year-to-year WBM fluxes of natural recharge and streamflow into and out of the basin (i.e., Sacramento Soil Moisture Accounting). This contribution adds information to current CONAGUA publications. The SAC-SMA model, which was constructed for the region as three sub-basins, uses hourly precipitation and evapotranspiration demand as model input to continuously simulate streamflow, soil moisture, actual evaporation from the soil, and groundwater recharge. The 
hourly precipitation time series for the SAC-SMA model was developed for 1954-2020 using a gauge located near the border and interpolated using monthly gridded climatology.

The average annual groundwater withdrawal amount that maintained sustainable conditions from 1954-2020 was 23.3 MCM/year. However, by implementing this constant annual withdrawal, there was a period of accrued surplus (1965-1993) followed by an accrued deficit (1994-2020). We also estimated the annual groundwater withdrawals that maintain sustainable conditions in a moving average of 20-year intervals, as recommended by ADWR for safe yield assessment in the SCAMA. For the analysis of the moving average of 20-year intervals, the groundwater withdrawal that maintained sustainable conditions peaked in 1993 at $36.4 \mathrm{MCM} /$ year and had since declined to less than $8 \mathrm{MCM} /$ year in 2020 . CONAGUA, in their latest groundwater availability report [23], estimated that groundwater withdrawal of $26.4 \mathrm{MCM} /$ year yields an additional 2.2. MCM/year of available water that could be allocated.

This study demonstrates the sensitivity of water resources management in the Mexican part of the Santa Cruz River basin and its high dependence on natural recharge, which depends on precipitation variability. It points to the challenge of identifying a management scheme that yields sustainable conditions. These challenges are exacerbated by the recent dry period and the projected uncertain precipitation in the region [12]. These mounting challenges call for careful adaptive management and planning of the aquifer to maintain sustainable conditions and long-term reliable water supply into the future.

Supplementary Materials: The following supporting information can be downloaded at: https: / / www.mdpi.com/article/10.3390/w14020233/s1, Figure S1: Average annual, summer (JJAS), and winter (NDJFM) rainfall over the USCRB (outlined in red). Data are available from the TerraClimate monthly $4 \mathrm{~km}^{2}$ 1958-2020 dataset, Figure S2: A scattergram of 1958-2020 monthly rainfall of the gauge record from Nogales $6 \mathrm{~N}$ and the matching grid cell available from the TerraClimate dataset, Figure S3: Locations of the of daily rain gauges, Figure S4: A comparison between the total summer rainfall cumulative distributions of the spatially disaggregated Nogales gauge (black) and seven rain gauge records (red). Note that the seven gauges have different durations, as indicated at the subplots' titles, Figure S5: A comparison between the total winter rainfall cumulative distributions of the spatially disaggregated Nogales gauge (black) and seven rain gauge records (red). Note that the seven gauges have different durations, as indicated at the subplots' titles, Figure S6: A scattergram of the summer (red) and winter (blue) total precipitation of the spatially disaggregated observed Nogales record compared with matched observed record from the seven gauges, Figure S7: The 1949-2020 cumulative distributions of simulated (red) and observed (black) streamflow on the Santa Cruz River at Lochiel for the summer, winter, and annual, Figure S8: The 1949-2020 cumulative distributions of simulated (red) and observed (black) streamflow on the Santa Cruz River at the Nogales gauge for the summer, winter, and annual.

Author Contributions: Conceptualization, E.M.T.-V., E.S., M.-B.C.-A. and S.B.M.; supervision, S.B.M. and E.M.T.-V.; methodology E.S., E.M.T.-V., M.-B.C.-A.; validation, E.S.; formal analysis, E.S.; investigation, E.S. and M.-B.C.-A.; resources, E.S. and M.-B.C.-A.; data curation, E.M.T.-V., E.S. and M.-B.C.-A.; writing — original draft preparation, E.M.T.-V., E.S.; writing—review and editing, E.S., M.B.C.-A. and S.B.M.; visualization, E.S., E.M.T.-V.; project administration, S.B.M.; funding acquisition, S.B.M. All authors have read and agreed to the published version of the manuscript.

Funding: This work was funded by the U.S. Geological Survey (funding authorized by P.L. 109-448) Award Number G17AC00439 for the Transboundary Aquifer Assessment Program.

Institutional Review Board Statement: Not applicable.

Informed Consent Statement: Not applicable.

Data Availability Statement: Not applicable.

Acknowledgments: The authors would like to acknowledge the Transboundary Aquifer Assessment Program (TAAP) and the administrative support of the Water Resources Research Center, University of Arizona. 
Conflicts of Interest: The authors declare no conflict of interest. The funders had no role in the design of the study; in the collection, analyses, or interpretation of data; in the writing of the manuscript, or in the decision to publish the results.

\section{References}

1. International Groundwater Resources Assessment Centre (IGRAC); UNESCO International Hydrological Programme (UNESCOIHP). Transboundary Aquifer of the World [Map]. Update 2021. 2020. Available online: https://www.un-igrac.org/news/igraclaunches-new-transboundary-aquifers-world-map-2021 (accessed on 6 November 2017).

2. Tapia-Villaseñor, E.M.; Megdal, S.B. The U.S.-Mexico Transboundary Aquifer Assessment Program as a Model for Transborder Groundwater Collaboration. Water 2021, 13, 530. [CrossRef]

3. Tapia-Villaseñor, E.M.; Shamir, E.; Megdal, S.B.; Petersen-Perlman, J.D. Impacts of Variable Climate and Effluent Flows on the Transboundary Santa Cruz Aquifer. JAWRA J. Am. Water Resour. Assoc. 2020, 56, 409-430. [CrossRef]

4. Megdal, S.B.; Scott, C.A. The Importance of Institutional Asymmetries to the Development of Binational Aquifer Assessment Programs: The Arizona-Sonora Experience. Water 2011, 3, 949-963. [CrossRef]

5. Callegary, J.B.; Megdal, S.B.; Tapia Villaseñor, E.M.; Petersen-Perlman, J.D.; Minjárez Sosa, I.; Monreal, R.; Gray, F.; Grijalva Noriega, F. Findings and lessons learned from the assessment of the Mexico-United States transboundary San Pedro and Santa Cruz aquifers: The utility of social science in applied hydrologic research. J. Hydrol. Reg. Stud. 2018, 20, 60-73. [CrossRef]

6. Skoulikaris, C. Transboundary Cooperation Through Water Related EU Directives Implementation Process. The Case of Shared Waters Between Bulgaria and Greece. Water Resour. Manag. 2021, 35, 4977-4993. [CrossRef]

7. Shamir, E.; Megdal, S.B.; Carrillo, C.; Castro, C.L.; Chang, H.-I.; Chief, K.; Corkhill, F.E.; Eden, S.; Georgakakos, K.P.; Nelson, K.M.; et al. Climate change and water resources management in the Upper Santa Cruz River, Arizona. J. Hydrol. 2015, 521, 18-33. [CrossRef]

8. Shamir, E. The value and skill of seasonal forecasts for water resources management in the Upper Santa Cruz River basin, southern Arizona. J. Arid Environ. 2017, 137, 35-45. [CrossRef]

9. Shamir, E.; Halper, E. The Role of Downscaling Methodology in Projected Climate Change Impacts on Water Resources in Arid Environments; Project ST-2016-9039; Research and Development Office, U.S. Department of Interior, Bureau of Reclamation: Denver, CO, USA, 2019.

10. IBWC. Joint Report of the Principal Engineers Regarding the Joint Cooperative Process United States-Mexico for the Transboundary Aquifer Assessment Program; International Boundary and Water Comission: El Paso, TX, USA, 2009.

11. Shamir, E.; Tapia-Villaseñor, E.M.; Cruz-Ayala, M.-B.; Megdal, S.B. A Review of Climate Change Impacts on the USA-Mexico Transboundary Santa Cruz River Basin. Water 2021, 13, 1390. [CrossRef]

12. Norman, L.M.; Feller, M.; Phillip Guertin, D. Forecasting urban growth across the United States-Mexico border. Comput. Environ. Urban Syst. 2009, 33, 150-159. [CrossRef]

13. Wilder, M.; Scott, C.A.; Pineda-Pablos, N.; Varady, R.G.; Garfin, G.M. Moving Forward from Vulnerability to Adaptation: Climate Change, Drought, and Water Demand in the Urbanizing Southwestern United States and Northern Mexico. (Avanzando desde la Vulnerabilidad hacia la Adaptación: El Cambio Climático, la Sequía, y la Demanda del Agua en Áreas Urbanas del Suroeste de los EEUU y el Norte de México; Udall Center for Studies in Public Policy, The University of Arizona: Tucson, AZ, USA, 2012.

14. Norman, L.; Tallent-Halsell, N.; Labiosa, W.; Weber, M.; McCoy, A.; Hirschboeck, K.; Callegary, J.; van Riper, C.; Gray, F. Developing an Ecosystem Services Online Decision Support Tool to Assess the Impacts of Climate Change and Urban Growth in the Santa Cruz Watershed; Where We Live, Work, and Play. Sustainability 2010, 2, 2044-2069. [CrossRef]

15. Norman, L.M.; Huth, H.; Levick, L.; Shea Burns, I.; Phillip Guertin, D.; Lara-Valencia, F.; Semmens, D. Flood hazard awareness and hydrologic modelling at Ambos Nogales, United States-Mexico border: Flood hazard awareness and hydrologic modelling at Ambos Nogales. J. Flood Risk Manag. 2010, 3, 151-165. [CrossRef]

16. Shamir, E.; Meko, D.M.; Graham, N.E.; Georgakakos, K.P. Hydrologic Model Framework for Water Resources Planning in the Santa Cruz River, Southern Arizona. J. Am. Water Resour. Assoc. 2007, 43, 1155-1170. [CrossRef]

17. Eden, S.; Megdal, S.B.; Shamir, E.; Chief, K.; Mott Lacroix, K.E. Opening the Black Box: Using a Hydrological Model to Link Stakeholder Engagement with Groundwater Management. Water 2016, 8, 216. [CrossRef]

18. Minjarez Sosa, I.; Monreal Saavedra, R.; Rangel Medina, M.; Grijalva Noriega, F.; Ochoa Granillo, J.A.; Tapia Villaseñor, E.M.; Ramírez Díaz, L.L.; Cirett Galán, S.; Moncada García, G.; Monijo González, A. Actividades Hidrogeológicas en el Acuífero Río Santa Cruz, Estado de Sonora, Primera Etapa; Universidad de Sonora: Hermosillo, Mexico, 2011.

19. Christopher, A. Scott, S.M.E.A. Effects of climate change and population growth on the transboundary Santa Cruz aquifer. Inter-Res. Sci. Cent. 2012, 51, 159-170.

20. CONAGUA. Determinación de la Disponibilidad de Agua en el Acuífero 2615 Río Santa Cruz, Estado de Sonora; Diario Oficial de la Federación (DOF): Ciudad de México, Mexico, 2009.

21. CONAGUA. Actualización de la Disponibilidad Media Anual de Agua en el Acuífero Río Santa Cruz (2615) Río Santa Cruz, Estado de Sonora; Diario Oficial de la Federación (DOF): Ciudad de México, Mexico, 2015; Available online: http://www.dof.gob.mx/nota_ detalle.php? codigo $=5389380 \&$ fecha $=20 / 04 / 2015$ (accessed on 2 January 2021). 
22. CONAGUA. Actualización de la Disponibilidad Media Anual de Agua en el Acuífero Río Santa Cruz (2615) Río Santa Cruz, Estado de Sonora; Diario Oficial de la Federación (DOF): Ciudad de México, Mexico, 2018; Available online: https://dof.gob.mx/nota_ detalle.php?codigo $=5510042 \&$ fecha $=04 / 01 / 2018$ (accessed on 2 January 2021).

23. CONAGUA. Actualización de la Disponibilidad Media Anual de Agua en el Acuífero Río Santa Cruz (2615) Río Santa Cruz, Estado de Sonora; Diario Oficial de la Federación (DOF): Ciudad de México, Mexico, 2020; Available online: https:/ / sigagis.conagua.gob. mx/gas1/Edos_Acuiferos_18/sonora/DR_2615.pdf (accessed on 2 January 2021).

24. Alley, W.M.; Reilly, T.E.; Franke, O.L. Sustainability of Ground-Water Resources; U.S. Dept. of the Interior, U.S. Geological Survey: Denver, CO, USA, 1999.

25. Alley, W.M.; Leake, S.A. The Journey from Safe Yield to Sustainability. Ground Water 2004, 42, 12-16. [CrossRef] [PubMed]

26. de Aguas Nacionales, L. Decreto por el que se Reforman, Adicionan y Derogan Diversas Disposiciones de la Ley de Aguas Nacionales; DOF: Ciudad de México, Mexico, 2004.

27. CONAGUA. Water Banks in Mexico; Ministry of the Environment and Natural Resources: Ciudad de México, Mexico, 2012.

28. OECD. Making Water Reform Happen in Mexico; OECD Studies on Water; OECD Publishing: Paris, France, 2013.

29. DOF. ACUERDO por el que se Actualiza la Disponibilidad Media Anual de Agua Subterránea de Los 653 Acuíferos de los Estados Unidos Mexicanos; DOF: Ciudad de México, México, 2020.

30. CONAGUA. Consulta a la Base de Datos del Registro Público de Derechos de Agua (REPDA). 2020. Available online: https: / /app.conagua.gob.mx/consultarepda.aspx (accessed on 15 July 2021).

31. Prichard, A.H.; Scott, C.A. Interbasin water transfers at the US-Mexico border city of Nogales, Sonora: Implications for aquifers and water security. Int. J. Water Resour. Dev. 2014, 30, 135-151. [CrossRef]

32. Data Mexico. Nogales: Economy, Employment, Equity, Quality of Life, Education, Health and Public Safety. Available online: https:/ / datamexico.org/en/profile/geo/nogales-30115 (accessed on 15 July 2021).

33. Sophocleous, M. From safe yield to sustainable development of water resources-The Kansas experience. J. Hydrol. 2000, 235, 27-43. [CrossRef]

34. Megdal, S.B. Arizona's 1980 Groundwater Management Act. Water Rep. 2012, 2012, 7.

35. Abatzoglou, J.; Dobrowski, S.; Parks, S.; Hegewisch, K. TerraClimate, a high-resolution global dataset of monthly climate and climatic water balance from 1958-2015. Sci. Data 2018, 5, 170191. [CrossRef] [PubMed]

36. Burnash, R.J.; Ferral, R.L.; McQuire, R.A. A Generalized Stream Flow Simulation System in Conceptual Modeling for Digital Computers, US National Weather Services: Sacramento, CA, USA, 1973.

37. ADWR. Groundwater Flow Model of the Santa Cruz Active Management Area along the Santa Cruz River and Nogales Wash from the International Border to Tubac; ADWR: Phoenix, AZ, USA, 2020.

38. Tapia Padilla, G. Aplicación de Modflow para la Simulación Hidrogeológica Estacionaria de una Porción de la Cuenca del río Santa Cruz, Sonora, México; Universidad de Sonora: Hermosillo, Mexico, 2005.

39. Técnicas Geológicas y Mineras. Estudio de Evaluación de la Disponibilidad De agua y Definición de Explotación en el Valle del Río Santa Cruz con Fines de Abastecimiento de Agua a la Ciudad de Nogales, Son; CONAGUA: Ciudad de México, México, 1989.

40. Aguilera, M.; Martínez, R. Relaciones Agua Suelo Planta Atmósfera; Universidad Autónoma de Chapingo: Estado de México, Mexico, 1996.

41. INEGI. Conjunto de datos vectoriales de la carta de Uso del suelo y vegetación. Escala 1:250,000. Serie VI. Conjunto Nacional. 2017. Available online: https://www.inegi.org.mx/app/biblioteca/ficha.html?upc=889463598459 (accessed on 2 January 2021). 